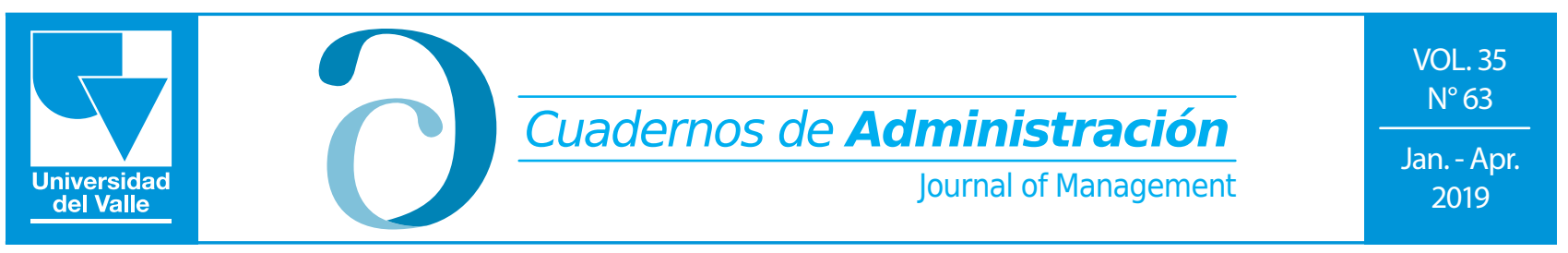

Print ISSN: 0120-4645 / E-ISSN: 2256-5078 / Short name: cuad.adm. / Pages: 89-100 Faculty if Administration Sciences / Universidad del Valle / Cali - Colombia

\title{
Diversification of the family business in emerging countries from the perspective of socio-emotional wealth. Literature Review
}

\author{
La diversificación del negocio familiar en países emergentes, desde la perspectiva de la \\ riqueza socioemocional. Revisión de la literatura
}

Diversification de l'entreprise familiale dans les pays émergents du point de vue de la richesse socio-affective. Revue de la documentation

\section{Silvia L. Corral ${ }^{1}$}

Professor, Member of the Center for Administration Studies, Faculty of Economics, Universidad Nacional del Centro de la Provincia de Buenos Aires, Buenos Aires, Argentina.

ORCID ID: https://orcid.org/0000-0002-9362-1492. e-mail: corral@econ.unicen.edu.ar

\section{Alfredo Rébori²}

Dean, Full Professor, Center for Studies in Administration, Faculty of Economics, Universidad Nacional del Centro de la Provincia de Buenos Aires, Buenos Aires, Argentina.

ORCID ID: https://orcid.org/0000-0002-3029-456X. e-mail: decano@econ.unicen.edu.ar

Review Article, PUBLINDEX-COLCIENCIAS classification
Submitted: 07/09/2018
Reviewed: $11 / 10 / 2018$
Accepted: $14 / 12 / 2018$
Core topic: Administration and Organizations
JEL classification: M1-M10
DOI: https://doi.org/10.25100/cdea.v35i63.6938

\section{Abstract}

The objective of this paper is to identify the relevant aspects studied in connection to the diversification of the family business that develops its activity in a business environment with unstable characteristics, considering those socio-emotional aspects that are particularly important for the family owner, and that could impact this election. The review reflects that research on the topic is in an incipient state. Studies conducted in the context of Taiwan predominate - where it is customary to establish business groups supported by strong links generated from a dominant family - and the strategic option of diversifying has been strongly associated with the purpose of securing family ownership and continuity in the business through generational transfer, dimensions that make up socio-emotional wealth. This paper contributes to reflect on the influence that family objectives exert on business decision-making and highlights the need for further research on the reasons behind the strategic choices of these organizations in different emerging markets.

Keywords: Family business, Diversification, Emerging market.

\section{Resumen}

El objetivo de este trabajo es identificar los aspectos relevantes estudiados en relación a la diversificación de la em-

BA in Administration, PhD student in Administration, Universidad Nacional del Centro de la Provincia de Buenos Aires, Argentina.

2 BA in Administration, Public Accountant, Doctor of Administration, Universidad Nacional del Centro de la Provincia de Buenos Aires, Argentina. 
presa familiar que desarrolla su actividad en un ambiente de negocios con características inestables, considerando aquellos aspectos socioemocionales que revisten particular importancia para la familia propietaria, y que podrían impactar en esta elección. La revisión realizada refleja que la investigación sobre el tópico se encuentra en estado incipiente. Predominan los estudios realizados en el contexto de Taiwán - donde es usual la constitución de grupos empresariales respaldados por los fuertes vínculos generados desde una familia dominante - y la opción estratégica de diversificar ha sido asociada fuertemente al propósito de asegurar la propiedad y continuidad de la familia en el negocio a través del traspaso generacional, dimensiones que componen la riqueza socioemocional. El artículo contribuye a reflexionar sobre la influencia que ejercen los objetivos familiares en la toma de decisiones empresariales y destaca la necesidad de una mayor investigación sobre las razones que impulsan las elecciones estratégicas de estas organizaciones, en diferentes mercados emergentes.

Palabras clave: Empresa familiar, Diversificación, Mercado emergente.

\section{Résumé}

L'objectif de ce travail est d'identifier les aspects étudiés pertinents à la diversification de l'entreprise familiale qui développe son activité dans un environnement d'affaires aux caractéristiques instables, en considérant les aspects socio-émotionnels qui revêtent une importance particulière pour le propriétaire familial, et qui pourraient avoir un impact sur ce choix. L'examen montre que la recherche sur des sujets d'actualité n'en est qu'à ses débuts. Les études sont prédominantes dans le contexte taïwanais - où il est habituel de former des groupes d'affaires soutenus par des liens solides générés par une famille dominante - et l'option stratégique de diversification a été fortement associée à l'objectif d'assurer la propriété et la continuité de la famille dans l'entreprise par le transfert générationnel, dimensions qui constituent la richesse socio-affective. L'article contribue à une réflexion sur l'influence des objectifs familiaux sur la prise de décision des entreprises et souligne la nécessité d'approfondir les recherches sur les raisons des choix stratégiques de ces organisations dans différents marchés émergents.

Mots-clés: Entreprise familiale, Diversification, Marché émergent.

\section{Introduction}

Diversification may result from the environment in which the firm operates, whether it has competitive conditions or instability and risk, although there are factors within the organization that also encourage the adoption of this strategy. Since the pioneering work of Ansoff (1958), researchers have promoted the interest in studying the different reasons that would lead an organization to opt for this business strategy. Nevertheless, in the context of family businesses, the analysis shows a certain degree of additional complexity since the influence of their owners - evidenced in the importance attached to the achievement of non-economic or affective nature objectives - has proved to be decisive in the behavior of these organizations (Gómez-Mejía, Haynes, Nuñez, Jacobson, and Moyano, 2007; Gómez Mejía, Makri, and Larraza Kintana, 2010; Kellermanns, Eddleston, and Zellweger, 2012; De Tienne and Chirico, 2013; Cabrera-Suárez, Déniz-Déniz, and Martín-Santana, 2014). In addition, it is noted that the prevailing reasons for family business diversification are an aspect not yet sufficiently explored in the context of emerging economies (Astrachan, 2010; Chung, 2013; Chang, Kao, and Kuo, 2014). From the perspective of this issue, the objective of this paper is to elaborate and integrate a review of the studies carried out around the strategic decision to diversify a family business in an unstable business environment, in which the impact of socioemotional factors by researchers has been addressed. For this purpose, publications in journals were reviewed in the field of Management between 2007 and 2018. The exploration reflects the prevalence of studies in Asian countries, those of recent years, and that the socio-emotional wealth approach contributes greatly to understanding how particular family objectives influence diversification decisions.

\section{Theoretical framework}

The methodology used consisted in selecting those empirical-nature papers published in scientific journals from 2007 and until May 2018 - the date when the exploration was undertaken - for which the ABInform, Econlit and Scopus databases were used as search engines. The selection of the base year to initiate the identification of publications was intentional, given that the concept of "socio-emotional wealth" was unveiled in a seminal paper published by Gómez-Mejía et al., (2007), in which they assert that the behavior of family companies is influenced by the emotional commitment of their members with the business.

The descriptors chosen to inaugurate the 
exploration were "socio-emotional wealth" - "emerging market" - "diversification", and only those papers that contained them in the title, abstract, or keywords were picked. By the same criteria, the search was completed with the terms "socio-emotional wealth" "diversification" and the combinations "family firms/family enterprises" - "diversification" "emerging market/country".

Then, to consider it in this review, firstly, the exploration was oriented and delimited towards those works in which the diversification of the family business - either geographical or by product - was addressed as a research topic considering the context in which the fieldwork was carried out. In this sense, the selection of papers took into account the country in which the study took place, based on the classification of developed, emerging and frontier markets, prepared by Morgan Stanley Capital International (MSCI). The search returned a total of 38 (thirtyeight) papers. First off, research conducted in countries categorized as developed by Morgan Stanley Capital International were dismissed: Germany (Kraus, Mensching, Calabró, Cheng, and Filser, 2016; Cesinger, Hughes, Mensching, Bouncken, Fredrich, and Kraus, 2016; Schmid, Ampenberger, Kaserer, and Achleitner, 2015); United
States (Essen, Carney, Gedajlovic, and Heugens, 2015; Memili, Fang, and Welsh, 2015; Campbell, Eden, and Miller, 2012); Austria (Wąsowska, 2017); United Kingdom (Wang, 2016); Australia (Ratten, Ramadani, Leo-Paul, Hoy, and Ferreira, 2017); Spain (Hernández-Trasobares and Galve-Górriz, 2015, 2016, 2017; Muñoz Bullon and Sánchez Bueno,2012); Italy (Pongelli, Caroli, and Cucculelli, 2016; Delbufalo, Poggesi, and Borra, 2016; Laffranchini and Braun, 2014; Majocchi and Strange, 2012); sample of Western European countries (Banalieva, Eddleston, and Zellweger, 2015); Singapore (Scholes, Mustafa and Chen, 2016). In the end, only 18 (eighteen) studies were identified within the established conditions, reflecting the embryonic state of the research within the framework of the three axes proposed in this work: diversification of the family business -unstable business environment- socioemotional perspective. The publications chosen were then analyzed based on the indicator given by the CiMago Journal Rank (SJR), set up according to the importance of the journal they come from and with a direct impact on the value of the published papers. It should be noted that there was no cap on this indicator, given the low number of findings. These are detailed in Table 1.

\begin{tabular}{|c|c|c|c|}
\hline \multicolumn{4}{|c|}{ Table 1. Works identified per journal } \\
\hline Journal & JSR 2017 Index & $\begin{array}{c}\text { Number of } \\
\text { publications }\end{array}$ & Research Context \\
\hline Journal of Management & 6.46 & 1 & Taiwan \\
\hline Organization Science & 5.5 & 1 & Taiwan \\
\hline Small Business Economics & 1.94 & 1 & Taiwan \\
\hline Industrial Marketing Management & 1.66 & 1 & Taiwan \\
\hline European Management Journal & 1.26 & 1 & Taiwan \\
\hline Journal of Business Research & 1.26 & 1 & Taiwan \\
\hline Asia Pacific Journal of Management & 1.185 & 1 & Thailand \\
\hline Asia Pacific Journal of Management & 1.185 & 1 & Malaysia \\
\hline Asia Pacific Journal of Management & 1.185 & 1 & Taiwan \\
\hline International Business Review & 1.01 & 2 & Taiwan \\
\hline North American Journal of Economics and Finance & 0.63 & 1 & Chile \\
\hline Journal of Management and Organization & 0.54 & 2 & Taiwan \\
\hline Journal of Small Business Strategy & 0.23 & 1 & Taiwan \\
\hline International Journal of Economics and Finance & 0.17 & 1 & Taiwan \\
\hline International Journal of Business and Economics & 0.19 & 1 & Taiwan \\
\hline International Review of Management and Business Research & 0.11 & 1 & Taiwan \\
\hline Total articles analyzed & & 18 & \\
\hline \multicolumn{4}{|c|}{ Source: Authors' own elaboration } \\
\hline
\end{tabular}




\section{Theoretical development}

When picking the papers that met the fixed limit conditions a classification of their contents was made. To this end, two questions were raised to which we sought to answer: 1) what theoretical approaches allow us to explain the impact of family influence on the business? and 2) from the perspective of socio-emotional wealth: how does this influence manifest itself in diversification decisions made in contexts with emergent characteristics? The following two sections will present the findings as follows: in the first (3.1), the concept of "socio-emotional wealth" is defined and reviews the theoretical approaches used by the researchers when approaching the study of the influence of the family on the company. The second section (3.2), presents in greater detail the research within the specific topic that this study proposes to analyze. Lastly, the authors' discussions or proposals for future research are included.

\subsection{The study of socio-emotional wealth: different approaches}

Socio-emotional wealth has received growing interest in recent years as it contributes to explaining the influence of the family in the business and behavior of these companies in relation to their strategic decisions and risk-taking; in this sense, this is framed within the Theory of Agency Behavior (Gómez-Mejía et al., 2007; Berrone, Cruz, and Gómez Mejía, 2012; Ding, Qu and $\mathrm{Wu}, 2016)$. The term has been conceived by Gómez-Mejía et al. (2007) to refer to certain aspects that the family decides to preserve in order to satisfy its non-economic needs, even to the detriment of greater profits for the company (Gómez-Mejía et al., 2007; Gómez Mejía, Cruz, Berrone, and De Castro, 2011). These aspects include maintaining control of the firm in the hands of the family, having family members identify with the company, safeguarding family ties and values, fostering commitment and handing the business over to future generations, dimensions that reflect the long-term orientation of these companies (Berrone et al., 2012). Debicki, Kellermanns, Chrisman, Pearson, and Spencer (2016) have recently defined it as the benefits associated with the welfare and affective needs of family members, reflecting the influence of the family in the business as well as the heterogeneity in the strategic behavior of these organizations ( Berrone, Cruz, GómezMejía, and Larraza-Kintana, 2010; Berrone et al., 2012; Cennamo, Berrone, Cruz, and Gómez - Mejía, 2012; Chrisman and Patel, 2012; De Tienne and Chirico, 2013; Kotlar, De Massis, Fang and Frattini, 2014).

The predominant theoretical approach in the analysis of the impact of family influence on the company has been the Agency Theory. Emphasizing on ownership, this framework assumes that owners and managers, or the agents of an organization, are driven by the opportunity to obtain personal benefits; in this way, they lead to the emergence of agency conflicts based on different interests and risk preferences (Jensen and Meckling, 1976). Notwithstanding, in the particular case of family businesses, the concentration of ownership has a positive impact on the reduction of tensions by enabling the alignment of family interests among its members (Schulze, Lubatkin, Dino, and Buchholtz, 2001; Miller, Le Breton-Miller and Lester, 2010; Hernández Trasobares and Galve-Górriz, 2015), so that possible resistance would be mainly tied to the different modes of family participation (Schulze et al., 2001; Songini and Gnan, 2015). Regarding the subject of this review, this theory has allowed us to explain: a) that a closed-family ownership structure becomes a restriction for business diversification, so these companies diversify less than non-family ones (Gómez-Mejía et al., 2007; 2010; Miller et al., 2010; Schmid et al., 2015; Delbufalo et al. 2016; Hernández Trasobares and Galve Górriz, 2015; 2017); b) a positive relationship between family ownership and non-economic objectives, even greater in the case of those firms in the hands of their founders (Berrone et al., 2012; Zellweger, Kellermanns, Chrisman, and Chua, 2012; Kotlar et al., 2014; Miller and Le Breton Miller, 2014; Memili et al.,2015; Kavadis and Castaner, 2015; Schulze, 2016). In addition, ownership patterns have been shown to influence the priorities given to the different dimensions that make up socio-emotional wealth (Le Breton Miller and Miller, 2013; Sciascia, Mazzola, and Kellermanns 2014; Minichilli, Brogi, and Calabro, 2016). As observed by Berrone et al. (2012), the Behavior Agency Theory does 
not contradict the core postulate of Agency Theory, since when the priority of the family owner is to protect socio-emotional wealth, he is expected to engage in opportunistic behaviors.

The influence of the family in the business has also sought to be explained through the Theory of Resources and Capabilities, as it argues that companies possess unique resources through which they can attain a competitive advantage, and explains that firms will choose to diversify when they have excess resources (Barney, 1991; Montgomery, 1994). In the particular case of family businesses, Habbershon and Williams (1999) coined the concept "familiarity" to refer to a unique and idiosyncratic set of tangible and intangible resources (such as networks of links, knowledge and a shared vision and purpose by family members). According to Astrachan, Klein, and Symrnios (2002), the source of the same is: 1) family ownership and participation; 2) the experience with which its members contribute to the business, which is activated in the process of generational transfer; 3) values rooted and shared in the company, which favor the commitment of the members of the family. Zellweger, Eddleston, and Kellermanns (2010) argue that the identity of its members, based on the perception of the company as a family business, is a fundamental pillar to these resources. When analyzed under the "familiarity" approach, business diversification may require additional material resources, as well as different skills and knowledge. This demand will then result in the need to recruit non-family staff and managers with these required skills. In this sense, the inflow of human resources from outside the family could be seen as an obstacle to preserving family independence and the resources already developed (Gómez-Mejía et al., 2010; Hernández Trasobares and Galve-Górriz, 2015, 2017). Scholes et al. (2016) demonstrate that the desire to maintain harmony and family ties has a negative impact on networking and development of new resources, and impacts internationalization activities beyond export.

Both concepts, "familiarity" and "socioemotional wealth", in addition to appearing as clear differentiators between family companies and non-family ones and collectively impacting strategic choices, business outcomes and survival (Chrisman, Sharma, Steier, and Chua, 2013; Chrisman and Patel, 2012; Sharma, Salvato, and Reay, 2014), are closely connected and are the result of the identification of their members in the business (Cabrera-Suárez et al., 2014). In connection thereto, given the objective of preserving socio-emotional wealth, and even though the company's resources are used inefficiently, it becomes difficult to transmit entrepreneurial orientation to the new generations (Schepers, Voordeckers, Steijvers, and Laveren,2014) as well as the practice of innovation activities (Chrisman and Patel, 2012; Kraiczy, Hack, and Kellermanns, 2015; Li and Daspit, 2016). Similarly, with regard to human resources, interest in increasing and maintaining their affectional endowment would lead owners to preserve the employment of family members in the company (Cruz, Justo, and De Castro, 2012; Cennamo et al.,2012; Memili, Misra, Chang, and Chrisman, 2013; Vandekerkhof, Steijvers, Hendriks, and Voordeckers, 2014).

Finally, it could be deduced that the approach of socio-emotional wealth largely captures that of Agency Theory and Resource and Capabilities Theory. In fact, retaining ownership control and transferring it to subsequent generations is one of their clearest objectives, as well as identifying family members in the business and protecting their own culture, which are sources of "familiarity" (Figure 1).

\subsection{Diversification of the family business in unstable markets, from the perspective of socio-emotional wealth}

Business diversification refers to a particular mode of strategy that requires changes in the market-product composition of a company that seeks to exit its current product line and market structure to enter new markets with new products, either within the limits of the industry in which it currently operates or outside of them (Ansoff, 1958). As already explained in the introduction, the purpose of this work is to conduct a review of the research that has deepened the approach of "socio-emotional wealth" in order to examine what has been written, specifically, regarding the decision to diversify a family 
Figure 1. Family influence: theoretical approaches

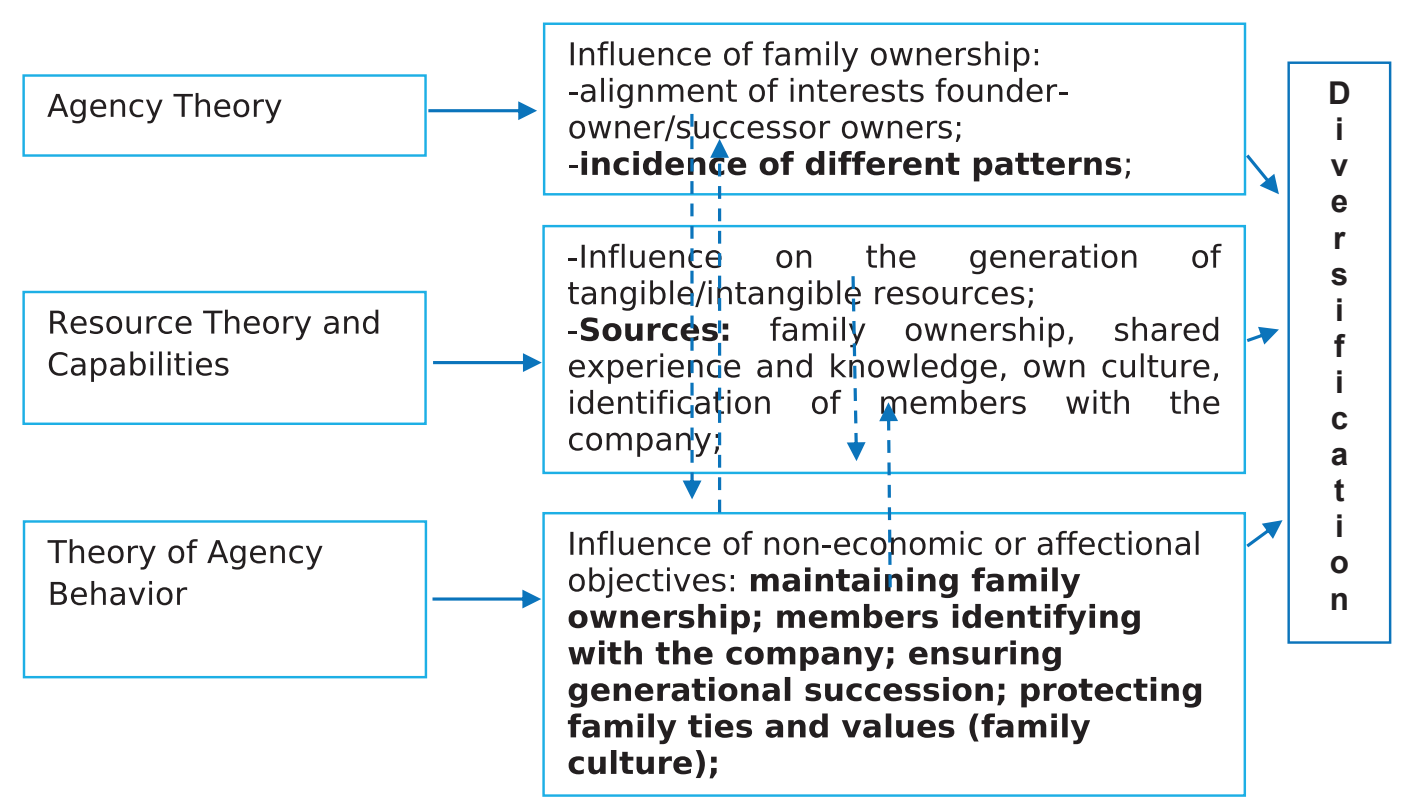

Source: Authors' own elaboration.

business in an environment characterized by economic unstable conditions, the lack of intermediaries, and underdeveloped institutions, which hinder trade (Khanna and Palepu, 2000). In the context of nonfamily businesses, the research conducted in contexts with these particularities has focused mainly on the relationship between the diversification strategy and business performance, showing that the so-called emerging countries face very different contingencies and need to evaluate factors such as government, political, economic and labor conditions, product life cycle and the characteristics of the competence (Sajid, Shujahat, and Mehmood, 2016). Overall, the results show that the benefits associated with diversification could be greater than the costs to the extent that companies can internally mimic market functions (Khanna and Palepu, 2000; Hoskisson, Johnson, Tihanyi, and White, 2005; Akben Selçuk, 2015), although a high degree of diversification could lead to diseconomies of scale since the inefficiency of markets leads to higher costs - such as coordination and information asymmetries - which add up to those resulting from managing new businesses in new segments (Yigit and Beharam, 2013; Akben Selçuk, 2015; Sajid et al., 2016).
Thus, if for family entrepreneurs the preservation of their non-economic objectives is a strategic priority, while environmental heterogeneity faces them with new challenges, it would be interesting to find out what has been studied regarding the reasons that drive family business owners to diversify when environmental conditions anticipate a certain level of insecurity.

The literature review reflects different research conducted in this field, as shown in Table 2.

The review reflects that the study of the decision to diversify a family business, considering the emergence of the contexts in which these companies operate, has been emerging in recent years and predominantly in Asian countries, where it is traditional to incorporate business groups based on economic and social ties, generally set up from a dominant family, with a critical role in economic activities. These groups act as an internal capital market and as a platform that allows them to share resources to affiliated companies, which are managed by the descendants of the main or other members of the family (Hsieh, Yeh, and Chen 2010; Chung, 2013; Wang, Chu, and Chen, 2013). In 
Table 2. Studies identified by author and year of publication

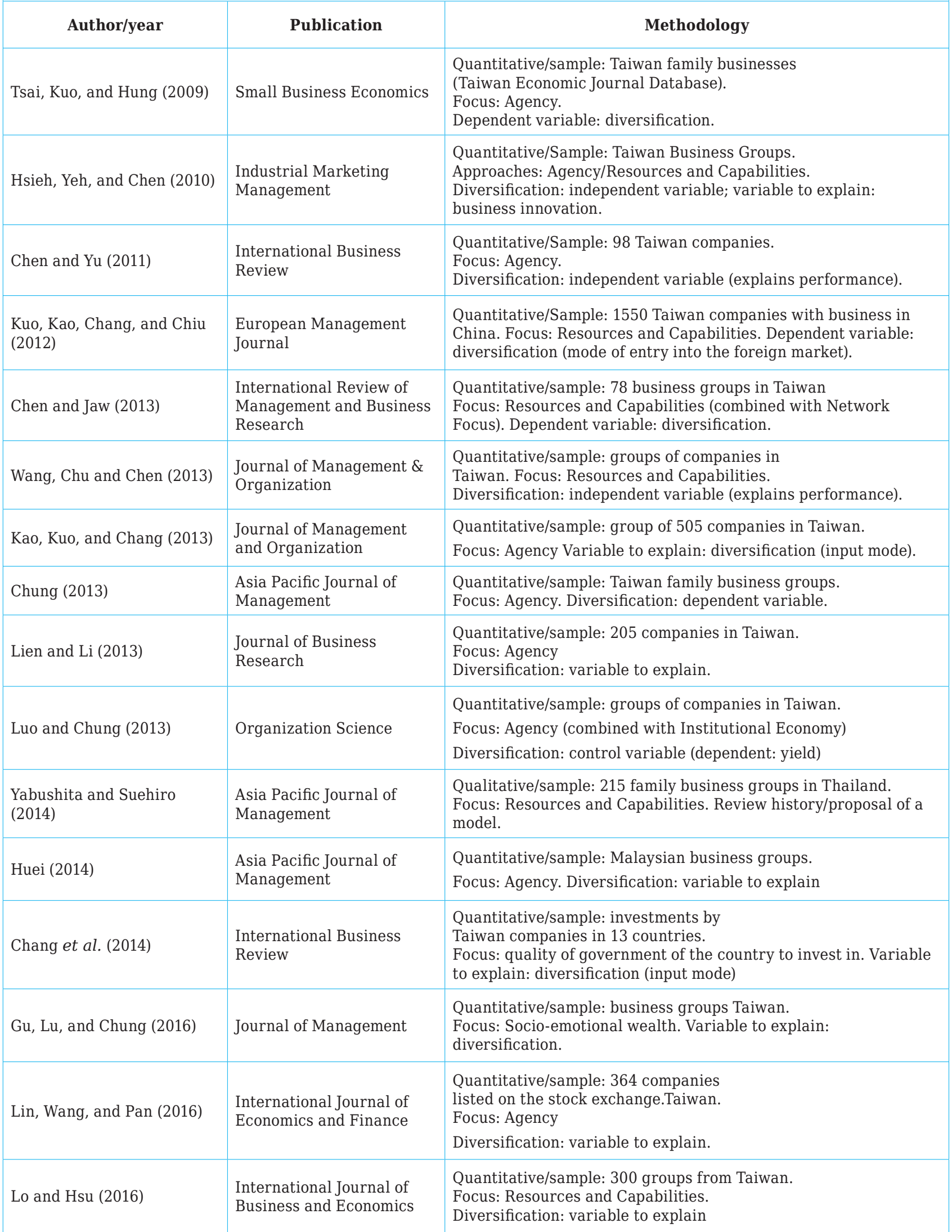




\begin{tabular}{|l|l|l|}
$\begin{array}{l}\text { Espinosa-Méndez, } \\
\text { Jara-Bertín, and Maquieira } \\
\text { (2018) }\end{array}$ & $\begin{array}{l}\text { North American Journal of } \\
\text { Economics and Finance }\end{array}$ & $\begin{array}{l}\text { Quantitative/sample: 104 Chilean companies. } \\
\text { Focus: Agency. } \\
\text { Diversification: variable to explain. }\end{array}$ \\
\hline $\begin{array}{l}\text { Tsao, Wang, W., Lu, Chen, } \\
\text { and Wang, J. (2018) }\end{array}$ & $\begin{array}{l}\text { Journal of Small Business } \\
\text { Strategy }\end{array}$ & $\begin{array}{l}\text { Quantitative/sample: Taiwan companies. } \\
\text { Focus: Socio-emotional wealth. } \\
\text { Diversification: independent variable (to be explained: incidence } \\
\text { of family ownership) }\end{array}$ \\
\hline
\end{tabular}

Source: Authors' own elaboration.

addition, it can be said that these companies bear broader levels of diversification in emerging markets to satisfy personal and family interests (Chen and Yu, 2011; Kuo, Kao, Chang, and Chiu, 2012; Lien and Li, 2013; Chung, 2013; Kao, Kuo, and Chang, 2013; Huei, 2014; Chang et al., 2014; Yabushita and Suehiro, 2014; Lin, Wang, and Pan, 2016; $\mathrm{Gu}, \mathrm{Lu}$, and Chung, 2016; Lo and Hsu, 2016; Tsao, Wang, Lu, Chen, and Wang, 2018), as this business strategy would provide the possibility of new units where descendants could operate (Lien and Li, 2013; Gu et al., 2016).

Strong family ties have positive effects on business innovation (Hsieh et al., 2010) and, while Luo and Chung (2013) argue that in these countries the control of the family would bring about better business performance, for the same reason it could be affected in different contexts, with similar characteristics (Wang et al., 2013; EspinosaMéndez, Jara-Bertín, and Maquieira, 2018). Chen and Jaw (2013) found that successors would be more willing to have fewer family members in the company, thus taking on the risks of diversification. In connection thereto, it is demonstrated that the preservation of the affectional endowment of the family as a framework for such decisions depends on the generation of owners in charge, which becomes stronger when the founding generation is in charge (Gu et al., 2016; Tsao et al., 2018). Chang et al. (2014), with regards to geographical diversification, add that these organizations are more aggressive when the quality of the government of the country in which they invest is higher, a behavior that relates to the concern of preserving a socioemotional wealth that is their own.

\section{Discussions}

Although the state of development of the research does not permit a more complete theoretical integration, the papers analyzed emphasize that the predominant focus to study this topic has been Agency Theory, and emphasize that in emerging countries diversifying a family business has been strongly associated with particular drivers of their owners, such as ensuring the continuity of the family in the business via ownership control, and handing the business over to the new generations. These reasons define two constituent dimensions of socio-emotional wealth and, in this sense, it can be said that the analysis supports the position of Berrone et al. (2012), when stating that these theoretical approaches are not invalidated.

The study admits as its major weaknesses the limited number of findings and, in addition, that they are concentrated in the context of Taiwan. However, it is expected to contribute to reflect on the impact of family objectives on business -even when the context poses conditions of instability and risk- and to assess the need for further research to be framed in different business environments with emergent characteristics, from the perspective of socio-emotional wealth and with a qualitative approach in order to gain: 1) a greater understanding of the strategic decision to diversify the family business in emerging countries and in which a different conformation of family organizations is present; and 2) to corroborate the importance acquired by socio-emotional aspects in these choices, and even identify which ones are identified as priorities under conditions of uncertainty.

\section{References}

Akben Selçuk, E. (2015). Corporate diversification and firm value: Evidence from emerging markets. International Journal of Emerging Markets, 10(3), 294-310.

Ansoff, H. I. (1958). A model for diversification. Management Science,4(4), 392-414. 
Astrachan, J., Klien, S., \& Smyrnios, K. (2002). The F-PEC scale of family influence: A proposal for solving the family business definition problem. Family Business Review, 15(1), 45-58.

Astrachan, J. (2010). Strategy in Family Business: toward a multidimensional research agenda. Journal of Family Business Strategy, 1, 6-14

Barney, J. B. (1991). Firm resources and sustained competitive advantage. Journal of Management, 17(1), 99-120.

Banalieva, E. R., Eddleston, K. A., \& Zellweger, T. M. (2015). When do family firms have an advantage in transitioning economies? Toward a dynamic institution-based view. Strategic Management Journal,36(9), 1358-1377

Berrone, P., Cruz, C., Gómez-Mejia, L., \& LarrazaKintana, M. (2010). Socioemotional wealth and corporate responses to institutional pressures: Do family-controlled firms pollute less? Administrative Science Quarterly, 55(1), 82-113.

Berrone, P., Cruz, C., \& Gómez Mejia, L. (2012). Socioemotional Wealth in Family Firms: Theoretical Dimensions, Assessment Approaches, and Agenda for Future Research. Family Business Review, 25(3), 258-279.

Campbell, J. T., Eden, L., \& Miller, S. R (2012). Multinationals and corporate social responsibility in host countries: Does distance matter. Journal of International Business Studies,43, 84-106.

Cabrera-Suárez, M. K., Déniz-Déniz, M. d. L. C., \& Martín-Santana, J. D. (2014). The setting of nonfinancial goals in the family firm: The influence of family climate and identification. Journal of Family Business Strategy, 5(3), 289-299.

Cennamo, C., Berrone, P., Cruz, C., \& GomezMejia, L. R. (2012). Socioemotional Wealth and Proactive Stakeholder Engagement: Why Family-Controlled Firms Care More About Their Stakeholders. Entrepreneurship Theory and Practice, 36(6), 1153-1173.

Cesinger, B., Hughes, M., Mensching, H., Bouncken, R., Fredrich, V., \& Kraus, S. (2016). A socioemotional wealth perspective on how collaboration intensity, trust, and international market knowledge affect family firms' multinationality. Journal of World Business, 51(4), 586-599.

Chang, Y.-C., Kao, M.-S., \& Kuo, A. (2014). The influences of governance quality on equitybased entry mode choice: The strengthening role of family control. International Business Review, 23(5), 1008-1020.
Chen, Y. Y., \& Jaw, Y. L. (2013). Does network cohesion impede diversification in the conglomerate? Evidence from Taiwanese business group. International Review of Management and Business Research, 2(2), 320-332.

Chen, C. J., \& Yu, C. M. J. (2011). Managerial ownership, diversification and firm performance: Evidence from an emerging market. International Business Review, 21, 518-534.

Chrisman, J. J., Sharma, P., Steier, L. P., \& Chua, J. H. (2013). The influence of family goals, governance, and resources on firm outcomes. Entrepreneurship Theory and Practice,37(6), 1249-1261.

Chrisman, J. J., \& Patel, P. C. (2012). Variations in $R \& D$ investments of family and nonfamily firms: behavioral agency and myopic loss aversion perspectives. Academy of Management Journal,55(4), 976.

Chung, H. M. (2013). The role of family management and family ownership in diversification: The case of family business group. Asia Management Journal,30(3), 871-891.

Cruz, C., Justo, R., \& De Castro, J. O. (2012). Does family employment enhance MSEs performance? Integrating Socioemotional Wealth and family embeddedness perspectives. Journal of Business Venturing, 27(1), 62-76.

Debicki, B., Kellermanns, F., Chrisman, J., Pearson, A., \& Spencer, B (2016) Development of a socioemotional wealth importance (SEWi) scale for family firm research. Journal of Family Business Strategy, 7(1), 47-57.

Delbufalo, E., Poggesi, S., \& Borra, S. (2016). Diversification, family involvement and firm performance. The Journal of Management Development, 35(5), 663-680.

De Tienne, D. R., \& Chirico, F. (2013). Exit strategies in family firms: How socioemotional wealth drives the threshold of performance. Entrepreneurship Theory and Practice, 37(6), 1297-1318.

Ding, S., Qu, B., \& Wu, Z. (2016). Family control, socioemotional wealth, and governance environment: The case of bribes. Journal of Business Ethics, 136(3), 639-654.

Espinosa-Méndez, C., Jara-Bertín, M., \& Maquieira, C. (2018). The influence of family and pyramidal ownership on corporate diversification in Chile. The North American Journal of Economics and Finance, 43(2018), 158-168. 
Essen, M., Carney, M., Gedajlovic, E. R., \& Heugens, P. P. M. A. R. (2015). How does family control influence firm strategy and performance? A meta-analysis of US publicly listed firms. Corporate Governance: An International Review, 23(1), 3-24.

Gómez-Mejía, L., Haynes, K., Nuñez, M., Jacobson, K., \& Moyano, J. (2007). Socioemotional wealth and business risks in family-controlled firms: Evidence from Spanish olive oil mills. Administrative Science Quarterly, 52(1), 106-137.

Gómez-Mejía, L., Makri, M., \& Lazarra Quintana, M (2010). Diversification Decisions in FamilyControlled Firms. Journal of Management Studies, 47(2), 223-252.

Gómez-Mejia, L., Cruz, C., Berrone, P., \& De Castro, J. (2011).The Bind that Ties: Socioemotional Wealth Preservation in Family Firms. The Academy of Management Annals, 5(1), 653-707.

Gu, Q., Lu, J. W., \& Chung, C. N. (2016). Incentive or Disincentive? A Socioemotional Wealth Explanation of New Industry Entry in Family Business Groups. Journal of Management, 20(10), 1-28.

Habbershon, T. G., \& Williams, M. (1999). A resource-based framework for assessing the strategic advantages of family firms. Family Business Review, 12, 1-25.

Hernández-Trasobares, A., \& Galve-Górriz, C. (2015). Does Concentration of Ownership and Family Control Affect Specialization/ Diversification Business Strategies? $E+M$ Ekonomie a Management, 18(4), 78-92.

Hernández-Trasobares, A., \& Galve-Górriz, C. (2016). Estrategias de diversificación en los grupos familiares y no familiares. Principales diferencias. Cuadernos de Gestión, 16(1). DOI: 10.5295/cdg.140509ah

Hernández-Trasobares, A., \& Galve-Górriz, C. (2017). Diversification and family control as determinants of performance: A study of listed business groups. European Research on Management and Business Economics,23(1), 46-54.

Hoskisson R. E., Johnson, R. A., Tihanyi, L., \& White, R.E. (2005) Diversified business group and corporate refocusing in emerging economies. Journal of Management, 31, 941-965

Hsieh, T., Yeh, R., \& Chen, Y. (2010). Business group characteristics and affiliated firm innovation: The case of Taiwan. Industrial Marketing Management, 39(4), 560-570.

Huei, N. S. (2014). How does group affiliation affect the diversification performance of familycontrolled firms in Malaysia? -A governance perspective. Asian Academy of Management Journal of Accounting and Finance, 10(2), 81-115.

Jensen, M. C., \& Meckling, W. H. (1976). Theory of the Firm: Managerial Behaviour, Agency Costs and Ownership Structure. Journal of Financial Economics, 3(4), 305-360.

Kao, M., Kuo, A., \& Chang, Y. (2013). How family control influences FDI entry mode choice. Journal of Management and Organization, 19(4), 367-385.

Kavadis, N., \& Castaner, X. (2015). Who drives corporate restructuring? Co-existing owners in french firms. Corporate Governance: An International Review, 23(5), 417-433.

Kellermanns, F. W., Eddleston, K. A., \& Zellweger, T. M. (2012). Extending the Socioemotional Wealth Perspective: A Look at the Dark Side. Entrepreneurship Theory and Practice, 36(6), 1175-1182.

Khanna, T., \& Palepu, K. (2000). Is group affiliation profitable in emerging markets? An analysis of diversified Indian business groups. Journal of Finance, 55(2), 867-891.

Kotlar, J., De Massis, A., Fang, H., \& Frattini, F. (2014). Strategic reference points in family firms. Small Business Economics, 43(3), 597-619.

Kraiczy, N. D., Hack, A., \& Kellermanns, F. W. (2015). What makes a family firm innovative? CEO risk-taking propensity and the organizational context of family firms. The Journal of Product Innovation Management, 32(3), 334-348.

Kraus, S., Mensching, H., Calabrò, A., Cheng, C., \& Filser, M. (2016). Family firm internationalization: A configurational approach. Journal of Business Research,69(11), 5473-5478.

Kuo, A., Kao, M., Chang, Y., \& Chiu, C. (2012). The influence of international experience on entry mode choice: Difference between family and non-family firms. European Management Journal, 30(3), 248-263.

Laffranchini, G., \& Braun, M. (2014). Slack in family firms: evidence from Italy (2006-2010). Journal of Family Business Management, 4(2), 171-193.

Le Breton-Miller, I., \& Miller, D. (2013). Socioemotional Wealth Across the Family Firm Life Cycle: A Commentary on "Family Business Survival and the Role of Boards". Entrepreneurship Theory and Practice, 37(6), 1391-1397. 
Li, Z., \& Daspit, J. (2016). Understanding family firm innovation heterogeneity: A typology of family governance and socioemotional wealth. Journal of Family Business Management, 6(2), 103-121.

Lien, Y. C., \& Li, S. (2013). Does diversification add firm value in emerging economies? Effect of corporate governance. Journal of Business Research,66, 2425-2430.

Lin, C., Wang, T., \& Pan, C. (2016). Financial reporting quality and investment decisions for family firms. Asia Pacific Journal of Management, 33(2), 499-532.

Lo, F-Y., \& Hsu, M-K. (2016). Business Group's Diversification Strategy and Sustainability. International Journal of Business and Economics, 15(1), 35-49.

Luo, X. R., \& Chung, C. (2013). Filling or abusing the institutional void? Ownership and management control of public family businesses in an emerging market. Organization Science, 24(2), 591-613.

Majocchi, A., \& Strange, R., (2012). International diversification. Management International Review, 52(6), 879-900.

Memili, E., Misra, K., Chang, E. P. C., \& Chrisman, J. J. (2013). The propensity to use incentive compensation for non-family managers in SME family firms. Journal of Family Business. Management, 3(1), 62-80.

Memili, E., Fang, H. C., \& Welsh, D. H. B. (2015) Value creation and value appropriation in innovation process in publicly-traded family firms. Management Decision, 53(9), 1921-1952.

Miller, D., Le Breton-Miller, I., \& Lester, R. H. (2010). Family ownership and acquisition behavior in publicly-traded companies. Strategic Management Journal, 31(2), 201-214.

Miller, D., \& Le Breton-Miller, I. (2014). Deconstructing socioemotional wealth. Entrepreneurship Theory and Practice, 38(4), 713-720.

Minichilli, A., Brogi, M., \& Calabro, A. (2016). Weathering the storm: Family ownership, governance, and performance through the financial and economic crisis. Corporate Governance: An International Review, 24(6), 552-568.

Montgomery, C.A.(1994). Corporatediversification. Journal of Economic Perspectives, 8(3), 163-178.

Muñoz Bullón, F., \& Sánchez Bueno, M.J. (2012). Do family ties shape the performance consequences of diversification? Evidence from the European Union. Journal of World Business, 47, 469-477.

Pongelli, C., Caroli, M. G., \& Cucculelli, M. (2016). Family business going abroad: The effect of family ownership on foreign market entry mode decisions. Small Business Economics,47(3), 787-801.

Ratten, V., Ramadani, V., Leo-Paul, D., Hoy, F., \& Ferreira, J. (2017). Family entrepreneurship and internationalization strategies, Review of International Business and Strategy, 27(2), 150-160.

Sajid, A., Shujahat, H. H., \& Mehmood, T. (2016). Corporate diversification and firm performance: An inverted U-shaped hypothesis. International Journal of Organizational Leadership, 5(4), 393-410.

Schepers, J., Voordeckers, W., Steijvers, T., \& Laveren, E. (2014). The entrepreneurial orientation-performance relationship in private family firms: The moderating role of socioemotional wealth. Small Business Economics, 43(1), 39-55.

Schmid, T., Ampenberger, M., Kaserer, C., \& Achleitner, A. (2015). Family firm heterogeneity and corporate policy: Evidence from diversification decisions. Corporate Governance: An International Review, 23(3), 285-302.

Scholes, L., Mustafa, M., \& Chen, S. (2016). Internationalization of small family firms: The influence of family from a socioemotional wealth perspective. Thunderbird International Business Review, 58(2), 131-146.

Schulze, W. S., Lubatkin, M. H., Dino, R. N., \& Buchholtz, A. K. (2001). Agency relationships in family firms: Theory and evidence. Organization Science, 12(2), 99-116.

Schulze, W (2016) Socio-emotional wealth and family: revisiting the connection, Management Research: Journal of the Iberoamerican Academy of Management, 14(3), 288-297.

Sciascia S., Mazzola P., \& Kellermanns F.W. (2014). Family management and profitability in private family-owned firms: Introducing generational stage and the socioemotional wealth perspective. Journal of Family Business Strategy,5(2), 131-137.

Sharma, P., Salvato, C., \& Reay, T (2014).Temporal Dimensions of Family Enterprise Research Family Business Review, 27(1), 10-19.

Songini, L., \& Gnan, L. (2015). Family Involvement 
and Agency Cost Control Mechanisms in Family Small and Medium-Sized Enterprises. Journal of Small Business Management, 53(3), 748-779.

Tsao, C.-W., Wang, M.-J., Lu, C.-M., Chen, S.-J., \& Wang, Y. (2018) Internationalization propensity in family-controlled public firms in emerging markets: The effects of family ownership, governance, and top management Journal of Small Business Strategy, 28(1), 28-37.

Tsai, W., Kuo, Y., \& Hung, J. (2009). Corporate diversification and CEO turnover in family businesses: Self-entrenchment or risk reduction? Small Business Economics, 32(1), 57-76.

Vandekerkhof, P., Steijvers, T., Hendriks, W., \& Voordeckers, W. (2014). The effect of organizational characteristics on the appointment of nonfamily managers in private family firms: The moderating role of socioemotional wealth. Family Business Review, $28,104-122$

Wang, C., Chu, W., \& Chen, C. (2013). Ownership, resources, and business-group effects on affiliate performance: Evidence from Taiwan. Journal of Management and Organization, 19(3), 255-278.

Wang, Y. (2016). Environmental dynamism, trust and dynamic capabilities of family businesses.
International Journal of Entrepreneurial Behavior \& Research, 22(5), 643-670.

Wąsowska, A. (2017). The internationalization of family firms: The role of the ownership structure and the composition of top management team. Entrepreneurial Business and Economics Review, 1(5), 169-185.

Yabushita, N. W., \& Suehiro, A. (2014). Family business groups in Thailand: Coping with management critical points. Asia Pacific Journal of Management, 31(4), 997-1018.

Yigit, I., \& Behram, N. K. (2013). The relationship between diversification strategy and organizational performance in developed and emerging economy contexts: the evidence from Turkey and Netherlands. Eurasian Business Review, 3(2), 121-136.

Zellweger, T., Eddleston, K., \& Kellermanns, F. (2010). Exploring the concept of Familiness: Introducing family firm identity. Journal of Family Business Strategy,1(1), 54-63.

Zellweger, T. M., Kellermanns, F. W., Chrisman, J. J., \& Chua, J. H. (2012). Family control and family firm valuation by family CEOs: The importance of intentions for transgenerational control. Organization Science, 23(3), 851-868.

¿How to quote this article?

Corral, S. L., \& Rébori, A. (2019). Diversification of the family business in emerging countries from the perspective of socio-emotional wealth. Literature Review. Cuadernos de Administración, 35(63), 89-100. DOI: https://doi. org/10.25100/cdea.v35i63.6938

Cuadernos de Administración journal by Universidad del Valle is under licence Creative Commons Reconocimiento-NoComercial-SinObrasDerivadas 4.0. Based in http://cuadernosdeadministracion.univalle.edu.co/ 